\title{
STUDI TENTANG PENGARUH KEPUASAN PELANGGAN TERHADAP EKUITAS MERK DAN WORD OF MOUTH PADA BENGKEL AHASS SEMARANG BARAT
}

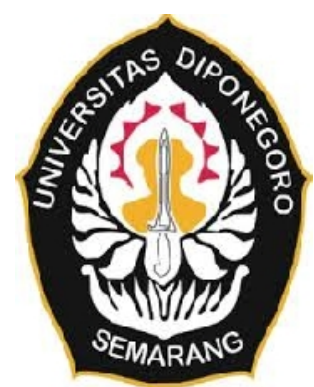

Tesis

Diajukan sebagai salah satu syarat untuk menyelesaikan Program Pascasarjana pada program Magister Manajemen Pascasarjana Universitas Diponegoro

Disusun oleh :

Eric Gunawan

12010115410049

PROGRAM STUDI MAGISTER MANAJEMEN

PROGRAM PASCASARJANA

UNIVERSITAS DIPONEGORO

2018 


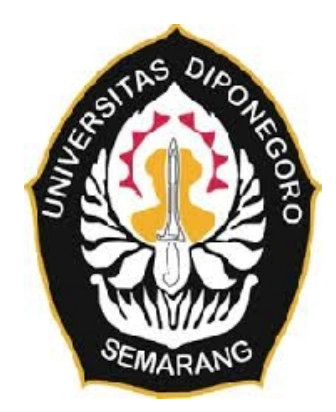

Sertifikat

Saya, Eric Gunawan, yang bertanda tangan dibawah ini menyatakan bahwa tesis yang saya ajukan ini adalah hasil karya saya sendiri yang belum pernah disampaikan untuk mendapatkan gelar pada program magister manajemen ini ataupun pada program lainnya. Karya ini adalah milik saya, karena itu pertanggungjawabannya sepenuhnya berada di pundak saya.

Eric Gunawan

16 Februari 2018 


\title{
PENGESAHAN TESIS
}

\section{Yang bertanda tangan di bawah ini menyatakan bahwa tesis berjudul : STUDI TENTANG PENGARUH KEPUASAN PELANGGAN TERHADAP EKUITAS MERK DAN WORD OF MOUTH PADA BENGKEL AHASS}

\author{
Yang disusun oleh Eric Gunawan, NIM 12010115410049 \\ telah dipertahankan di depan Dewan Penguji pada tanggal 14 Maret 2018 dan \\ dinyatakan telah memenuhi syarat untuk diterima
}

Pembimbing Utama

Pembimbing Anggota

I Made Sukresna, SE., Msi., Ph. D

Dr. Sugiono, MSIE

\author{
Semarang, 18 Maret 2018 \\ Universitas Diponegoro \\ Program Pascasarjana Program \\ Program Studi Magister Manajemen \\ Ketua Program
}

Dr. Susilo Toto Raharjo, MT 


\begin{abstract}
This research was conducted with the aim to see the influence of Customer Satisfaction on Brand Equity and Word of Mouth in AHASS workshop. The added variables are Service Quality and Perceived Price as Moderating Variables that affect Customer Satisfaction.

The sample of this research is the customers of AHASS Workshop in Semarang city of West. Analysis of Structural Equation Model (SEM) data using AMOSS and SPSS software programs. The result of the analysis shows that Customer Satisfaction has positive effect on Brand Equity and Word of Mouth. Service Quality positively affects Customer Satisfaction moderated by Perceived Price as Quasi Moderator.

The most dominant variable is Customer Satisfaction. If consumers are satisfied with the services provided, then consumers will be able to market word of mouth about AHASS workshops. In addition, satisfied customers will not move to another workshop. Customer Satisfaction is affected by Service Quality and Perceived Price. Good service and price in accordance with the service will make the customer satisfied to servicing his vehicle in AHASS workshop.
\end{abstract}

Key Word: Service Quality, Customer Satisfaction, Brand Equity, Word of Mouth, Perceived Price 


\begin{abstract}
ABSTRAK
Penelitian ini dilakukan dengan tujuan untuk melihat pengaruh Customer Satisfaction terhadap Brand Equity dan Word of Mouth pada bengkel AHASS. Variabel yang ditambahkan adalah Service Quality dan Perceived Price sebagai Moderating Variabel yang berpengaruh terhadap Customer Satisfaction.

Sampel penelitian ini adalah para pelanggan Bengkel AHASS kota Semarang bagian Barat. Analisis data Structural Equation Model (SEM) menggunakan program software AMOSS dan SPSS. Hasil analisis menunjukkan bahwa Customer Satisfaction berpengaruh positif terhadap Brand Equity dan Word of Mouth. Service Quality berpengaruh positif terhadap Customer Satisfaction yang dimoderasi oleh Perceived Price sebagai Quasi Moderator.

Variabel yang paling dominan adalah Customer Satisfaction. Apabila konsumen merasa puas terhadap pelayanan yang diberikan, maka konsumen akan dapat memasarkan dari mulut ke mulut tentang bengkel AHASS. Selain itu, pelanggan yang puas tidak akan berpindah ke bengkel lain. Customer Satisfaction ini dipengaruhi oleh Service Quality dan Perceived Price. Pelayanan yang baik serta harga yang sesuai dengan pelayanan akan menjadikan pelanggan puas untuk menservis kendaraannya di bengkel AHASS.
\end{abstract}

Kata kunci : Service Quality, Customer Satisfaction, Brand Equity, Word of Mouth, Perceived Price 


\section{KATA PENGANTAR}

Puji syukur kepada Tuhan Yang Maha Esa, atas rahmat dan bimbingan - Nya penulis dapat menyelesaikan tesis dengan judul "Studi tentang Pengaruh Customer Satisfaction terhadap Brand Equity dan Word of Mouth pada Bengkel AHASS". Tujuan penulisan tesis ini adalah sebagai salah satu syarat untuk menyelesaikan Program Magister Manajemen pada Program Pasca Sarjana Universitas Diponegoro.

Pada kesempatan ini, penulis juga berterima kasih kepada :

1. Dr. Susilo Toto Raharjo, MT., selaku Ketua Program Studi Magister Manajemen Universitas Diponegoro.

2. I Made Sukresna, Ph.D. selaku Dosen Pembimbing utama dalam penulisan tesis ini.

3. Dr. Sugiyono, M.Sie., selaku Dosen Pembimbing anggota dalam penulisan tesis ini.

4. Responden Bengkel AHASS kota Semarang Barat.

5. Gunawan Widjaja dan Martha Kristiani selaku orang tua yang dengan begitu setia mendukung dan memberi semangat pada penulis.

6. Vania Gunawan selaku kakak kandung penulis yang memberikan saran dan kritik terhadap penulisan tesis.

Penulisan tesis ini tidaklah sempurna, apabila terdapat kesalahan dan kekeliruan di dalamnya, penulis memerlukan kritik dan saran demi penyempurnaan tesis ini. 
Akhir kata, penulis berterima kasih dan berharap tesis ini dapat bermanfaat bagi pembaca serta bagi dunia pendidikan. Terima kasih atas perhatiannya.

Semarang, 16 Februari 2018

Eric Gunawan 